\title{
TAX REFORM AND NONCOMPLIANCE IN INDONESIA
}

\author{
Heru Iswahyudi \\ Ministry of Finance of the Republic of Indonesia*, Indonesia \\ (heru.iswahyudi@gmail.com)
}

\begin{abstract}
The purpose of this paper is to examine the impact of Indonesia's tax reforms of 2000 and 2008/2009 on taxpayers' noncompliance. Noncompliance is defined as the difference between the Value Added Tax (VAT) liability and the actual revenue. Data are mainly collected from the World Input-Output Database and Indonesia's Central Board of Statistics. The methodology uses one of the 'top-down' approaches, in which national accounts figures are employed to arrive at an estimation of the VAT liability. It is found that compliance deteriorated when reform efforts were incomplete - that is when the reforms suffered from decelerations, setbacks or reversals. This paper contributes to the literature by providing a framework for analyzing the impact of tax reform on taxpayer's compliance behavior.
\end{abstract}

Keywords: tax reform, noncompliance, value added tax, tax administration, Indonesia

\section{INTRODUCTION}

Tax noncompliance is present in all economies using taxes to finance government expenditures (Eichhorn, 2004; Freire-Serén \& i Martí, 2013). For Indonesia, tax noncompliance has challenged the recent governments' ambitious economic development projects, particularly those for enhancing infrastructure and expanding the social safety net, which require significant increases in public revenues.

The tax gap - which is the difference between the actual collection and its potential may rise due to government policy and taxpayer noncompliance. A policy gap occurs from deliberate government policies that provide incentives and facilities in taxation, such as reduced rates and exemptions. The compliance gap arises from taxpayers' nonconformity with the tax laws, either legally through tax avoidance measures, or illegally through tax evasion. It may be important to analyze both gaps separately. This paper only discusses the compliance gap, however, because in the context of Indonesia this estimation is crucial for

\footnotetext{
* This paper was prepared in author's personal capacity. The opinions expressed in this article are the author's own and do not reflect the view of the organization with which the author affiliated.
}

assessing the results of two tax reform programs (which were launched after the Asian financial crisis of 1998) on taxpayers' compliance behavior.

Nevertheless, time series research on Indonesia's tax noncompliance is rare, thus its trend over time has rarely been examined. Ikhsan, Trialdi, and Syahrial (2005) estimated the Indonesian tax gap using national survey data from 2003 and found that collection only covers 43 percent of the potential for personal income taxes and around 50 percent for VAT. Still, their study only examines the tax gap at a point in time, the year 2003. Hence, a more complete picture of the trend of noncompliance over time may be needed to examine whether it has been improving or deteriorating, assess its proximate causes and formulate appropriate policies.

In this paper, the estimation of the Value Added Tax (VAT) gap is chosen as the benchmark for analyzing noncompliance, because nonconformity with this type of tax is likely to be followed by noncompliance with income tax. The invoice-and-credit design of VAT should make nonconformity easier to detect than in other types of taxation, at least theoretically. Hence, when taxpayers fail to 
report or under report their VAT liabilities, it is likely that they would also fail to report or under report their income tax liabilities, in order to avoid detection.

The rest of this paper is organized as follows. The second section overviews the introduction of VAT in Indonesia and its collection performance to date. The third section discusses the problems with VAT compliance, including how its invoice-and-credit design could be fraudulently exploited. The fourth section explains the methodology and data employed to arrive at the estimations of the VAT gap. The fifth section presents the results and discusses how incomplete reforms might contribute to increases in the VAT gap. Section six presents the concluding remarks.

\section{VAT IN INDONESIA}

In 1984, Indonesia enacted a major tax reform, which represented a significant departure from the tax system adopted since the country's independence. At the time of the reform, there were acknowledged defects in the existing tax structure and tax administration. Many of these defects could be attributed to the generally unsuccessful policies to fine-tune the tax system to support nonrevenue objectives, such as industrial growth, regional development and income redistribution (Gillis, 1989).

One of the centerpieces of the reform was the introduction of VAT to replace an outdated sales tax which was riddled with exemptions and used complex, multiple rates. Indonesia's VAT is broadly due on events involving the delivery of taxable goods or services. A single rate of 10 percent applies on domestic sales and imports while exports are subject to zero-rating. A legal negative list sets out which goods and services were exempted from the tax. This list includes basic commodities (such as rice, corn and soy), mining products and meritorious services (such as education, health and cultural services). Moreover, some goods which are considered 'luxury' are subject to a luxury sales tax. This tax generates an insignificant tax revenue, however, and was introduced mainly to protect the integrity of the uniform VAT rate and improve the political acceptability of the 1984 tax reform package (Gillis, 1989).

Nevertheless, even after more than three decades of reform the narrow tax base still serves as a challenge in the effort to collect taxes. Figure 1 shows Indonesia's tax revenues, as a percentage of GDP, compared with its neighboring countries, as of 2014. Only Malaysia collected less tax on goods and services (although much more income tax revenue) than Indonesia. While Korea, Thailand, Malaysia and Singapore collected tax on goods and services, on average, at 5.4 percent of GDP, Indonesia only managed to collect 3.9 percent of GDP. Overall, Indonesia's total tax revenue, as a percentage of GDP, is the lowest among these countries. The country's minister of finance once stated that out of a population of 250 million, only 27 million registered as individual taxpayers and only 900 thousand individuals, or 3 percent of those registered, actually pay taxes (Utami, 2016).

When properly administered, VAT may have more revenue potential than other alternative indirect taxes: it could help improve tax compliance and enforcement, due to the trail of invoices the system creates, it is generally more broad based and could minimise the cascading effect of taxation (Le, 2003). Nevertheless, one of the possible causes for the limited gains in VAT may come from the taxpayers' noncompliance with the tax laws. Results from empirical studies show positive associations between the level of development of a country and its VAT performance. Countries with a lower level of per capita income, a higher share of the agriculture sector in GDP and a lower level of literacy tend to have a lower level of VAT collection (Ebrill, Keen, Bodin, \& Summers, 2001). 


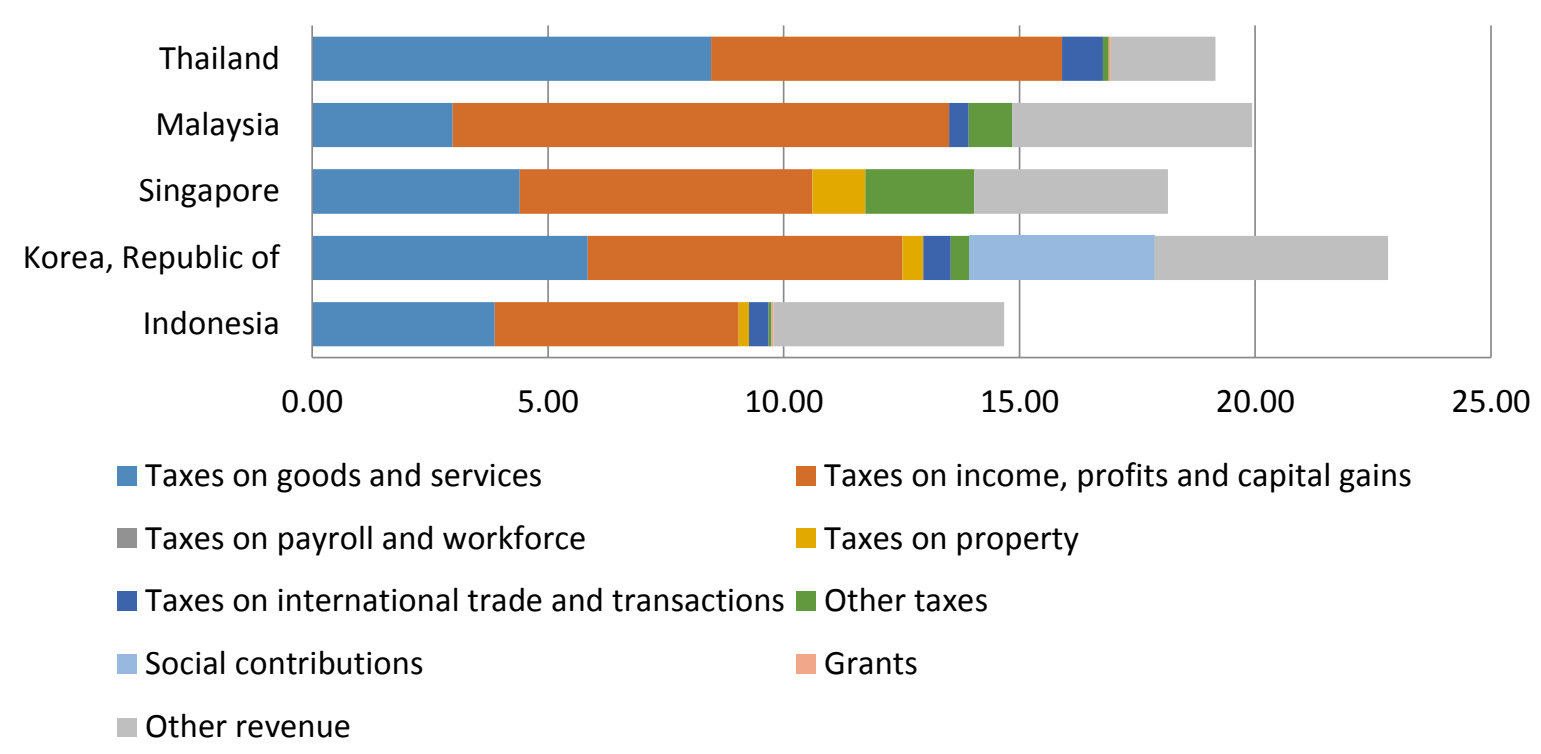

Figure 1. Tax revenues as percentage of GDP, 2014

Sources: Badan Pusat Statistik (Various Years); World Economic Outlook (2016).

\section{VAT NONCOMPLIANCE}

In this paper, VAT noncompliance is defined as the gap or the difference between the potential and actual yields of the tax, due to taxpayers' noncompliance. This gap should be distinguished from the policy gap which refers to the impact on the potential yield of the tax, due to government policies such as exemptions, zero-ratings and other reductions to the potential tax base (Hutton, Thackray, \& Wingender, 2014).

Although tax noncompliance is not confined to VAT, its advocates argue that the invoiceand-credit design of VAT should make this practice easy to detect by the authorities, since it entails a trail of invoices (Agha \& Haughton, 1996; Barbone et al., 2013; Kopczuk \& Slemrod, 2006). Further, VAT is levied on the sale of goods and services at each stage of the production chain, as well as the distribution chains and the tax paid will be refundable only to registered businesses. Theoretically, this design provides an incentive for businesses to register themselves with the tax authority, since non-registered, tax-evading businesses would still be liable for the VAT on their purchase of inputs, but without the right to recover the input's tax. With this mechanism, proponents of VAT describe the tax as 'self-enforcing' since taxable businesses have strong incentives to keep invoices of their transactions, thus the paper trails may provide an efficient means for tax authorities to audit for enforcement purposes (Le, 2003).

In practice, however, there are many ways in which VAT can be evaded or fraudulently exploited. The listing that follows is from Smith and Keen (2007) and is not intended to be complete:

- Under-reported sales. A taxable business may report only a certain proportion of sales or treat some sales as completely 'off the books'. It may or may not issue invoices for its sales, particularly for sales to final consumers, since no credit would be available for these consumers. Common examples of this group are personal services such as hairdressing and home decorating In these types of activities, however, the value added at the final stage is usually large, relative to the input VAT.

- Failure to register. Many VAT regimes oblige taxable businesses to register when their turnover exceeds a certain threshold. 
Businesses with turnover levels close to the threshold, however, may fail to register and they may evade both income tax and VAT.

- Tax collected but not remitted. Registered businesses may charge VAT to their customers but then fail to pay the tax to the authorities, either by falsifying their accounting records, engineering their bankruptcy before the tax is paid, or by just disappearing.

- False claims for credit or refunds. Invoices could be forged, thus purchases may be exaggerated to minimise the difference between the output and input VAT which has to be paid to the government. An intrinsic difficulty with VAT is the zero-rating of exports, which might encourage fraudulent claims to have exported commodities when in reality such exports may not occur, or the commodities have been sold in the domestic market.

- VAT credit claimed for purchases that are not creditable. One of the examples of this scheme is the purchase of items for private consumption which are misrepresented as business inputs, in order to recover the VAT and reduce income tax liabilities.

- Bogus traders. It is practically impossible for tax authorities to cross-check every invoice against evidence that the earlier tax has been paid. Exploiting this weakness, 'invoice mill' companies could be set up with the sole purpose of generating bogus invoices that allow the recovery of VAT.

Studies have found that the invoice-andcredit design of VAT may create a chain effect reaction when noncompliance is practiced in one of the stages of production or distribution. From a survey of small firms in Brazil, De Paula and Scheinkman (2010) examined the role of VAT in transmitting informality and noncompliance. They found that firms' tax noncompliance is correlated to the informality of their suppliers or customers. Thus, when there is a high tolerance for the informality of firms in one production stage, tax noncompliance in the downstream and upstream stages would increase. This result confirms the impact of VAT in spreading tax noncompliance.

Similarly, from field experiments in Chile, Pomeranz (2015) shows that VAT noncompliance behavior cascades through the production and distribution chains. Hence, Pomeranz (2015) argued that an optimal tax audit strategy would have to consider the multiplier effect through the audited firm's trading network, rather than focusing solely on the deterrence effect on the audited firm.

These studies show that maintaining and monitoring VAT may increase the compliance costs of the audited firms and the administrative costs of the tax agency. These costs may divert resources from more productive activities and represent a burden to the economy (Berhan \& Jenkins, 2005).

In summary, the argument for the selfenforcing mechanism of VAT might need to be carefully scrutinized. Empirical studies (see Barbone et al. (2013); Keen and Smith (2006); Reckon (2009), for examples) found that many countries face the problem of VAT noncompliance. Hence, to get the most optimal gains from VAT, knowing the potential tax base and the level of noncompliance for the aggregate economy may be a good starting point.

\section{METHODOLOGY AND DATA}

The VAT gap due to noncompliance is defined as the difference between the VAT Total Theoretical Liability (VTTL) and the actual VAT revenue. The methodology to calculating the VTTL follows Barbone et al. (2013). It is one of the 'top-down' approaches in which national accounts figures are used to arrive at an estimation of the VAT liability generated by different sub-aggregates of the economy. In the VAT system, final consumers pay the tax on their purchases of taxable goods and services, while producers pay the tax on the inputs consumed when producing non-taxable or exempt goods and services. Hence, there are two major components in VTTL: the VAT paid by final consumers and the VAT paid by producers. Thus, VTTL could be expressed as: 

$\sum_{\{i \text { : all final taxable purchases by consumers }\}}$ value $_{i}$. VAT rate r $_{i}+$

$\sum\{j:$ all purchases of intermediate inputs used for production of exempt goods $\}$ value ${ }_{j}$. VAT rate r $_{j}$

In the absence of complete data on all the individual purchases by consumers and producers, VAT Liability (VTL) is estimated using the national accounts aggregate. One of the main data sources is the World Input-Output Database (WIOD). ${ }^{1}$ WIOD provides aggregate data on the purchases of goods and services and classifies these data into consumption (intermediate and final), investment and exports. While exports are subject to zero-rating, consumption and investment purchases can generate a VAT liability.

Regarding the source of data, another alternative would be to use Indonesia's InputOutput (IO) table, published by the Central Board of Statistics (Badan Pusat Statistik, BPS). Nevertheless, the problem is that Indonesia's IO table only comes out at discreet intervals of about once every five years, hence a yearly examination would not be feasible. For this reason WIOD is used in this paper since it provides yearly data.

VTTL is computed as the sum of three different components: VTL from final consumption, VTL from intermediate consumption with non-deductible VAT and VTL from investment. The VTL from final consumption is estimated as the sum of the values of the final consumption of goods and services, which WIOD separates into three categories: households, government and NonProfit Institutions Serving Households (NPISH). These consumptions are multiplied by the VAT rate to arrive at the VTL from final consumption. $^{2}$

The VTL from intermediate consumption is estimated as the sum of the values of intermediate consumption for each of the 36 industries, as classified in WIOD, times the VAT rate times each industry's proportion of non-

\footnotetext{
1 http://www.wiod.org/new_site/database/niots.htm

2 VAT rate in Indonesia stays unchanged at 10 percent for the period under study.
}

deductible VAT or the "propex" factor (Reckon, 2009). Since VAT exemptions vary over time, by examining the tax regulations on VAT exemptions over the study period, the propex for an industry in a particular year is set to one if all the goods or services produced by that industry are exempted in that year. If, in a particular year, no goods or services produced by a particular industry are exempted, the propex for that year is set to zero. The propex is estimated to be equal to the share of the exempt output in an industry's total output, if only a portion of the goods or services produced by the industry are exempted. This estimation involves the assumption that the share of exempted goods or services in an industry's output is equal to the proportion of inputs used by that industry to produce the exempt goods or services.

The VTL from investment purchases consists of two components: Gross Fixed Capital Formation (GFCF) and changes in inventories and valuables. The VTL is estimated as the sum of the values of investment purchases times the VAT rate times the propex factor. Neither data from WIOD nor from Indonesia's Central Board of Statistics have any information on the values of investment purchases by each industry. In the absence of such data, the values of GFCF, as well as changes in inventories and valuables, are assigned from WIOD to each of its 39 categories (36 industries plus households, government and NPISH), based on the proportion of consumption of each category to the total consumption. This calculation involves the assumption that the share of capital expenditure is equal to the share of goods and services consumed. The propex factor for industries follows the calculations determined previously in estimating the VTL from intermediate consumptions.

Since WIOD only contains data from 1995 to 2011, the VTTL is estimated for 2012-2015 by dividing each year's Gross Domestic Product (GDP) into each of the 39 different categories. The base for the allocation is the average share 
of each category's consumption to GDP during the years covered in WIOD, with the assumption that this ratio does not change over time.

\section{RESULTS}

Figure 2 shows the estimates of the VAT gap due to noncompliance in Indonesia, over the period 1995-2015. The gap widened significantly in the years following the Asian financial crisis of 1998, from around 9 percent of GDP in 1995 to around 11 percent in 1999. This was a period of turbulence. During and after the fall of the regime of Suharto in 1998, mass street protests, inter-ethnic unrest and increasing separatism occurred simultaneously. It might not be too difficult to envisage the problems faced by tax collectors in that kind of environment. As the threats of unrest eased - at the same time there was a tax reform launched in $2000-$ Indonesia's VAT gap started to decline and it reached its lowest level of around 6 percent of GDP in 2010. However, the gap has shown an increasing trend again since 2011, and reached around 8 percent of GDP in 2015 - even though there was another tax reform launched in 2008/2009.

The crisis adversely impacted the country's fiscal conditions, among others. Thus, one of the approaches taken to improve the fiscal sustainability was reforming the tax system and the main point of the reform of 2000 was improvements in the tax administration. It can be argued that an emphasis on tax administration has its merits, because for developing countries making a formal distinction between their tax policy and tax administration may be pointless. This is due to the interdependent nature of these two domains - well designed tax policies can easily be undermined by poor administration. This does not negate the importance of good tax policies, since complex tax codes, schedules and procedures tend to increase the scope for avoidance and evasion. Nevertheless, the essence of a good tax policy - particularly for developing countries - is one which can be easily administered (Moore, 2013). This view is consistent with Casanegra de Jantscher (1990) who argued that in developing countries, 'tax administration is tax policy'.

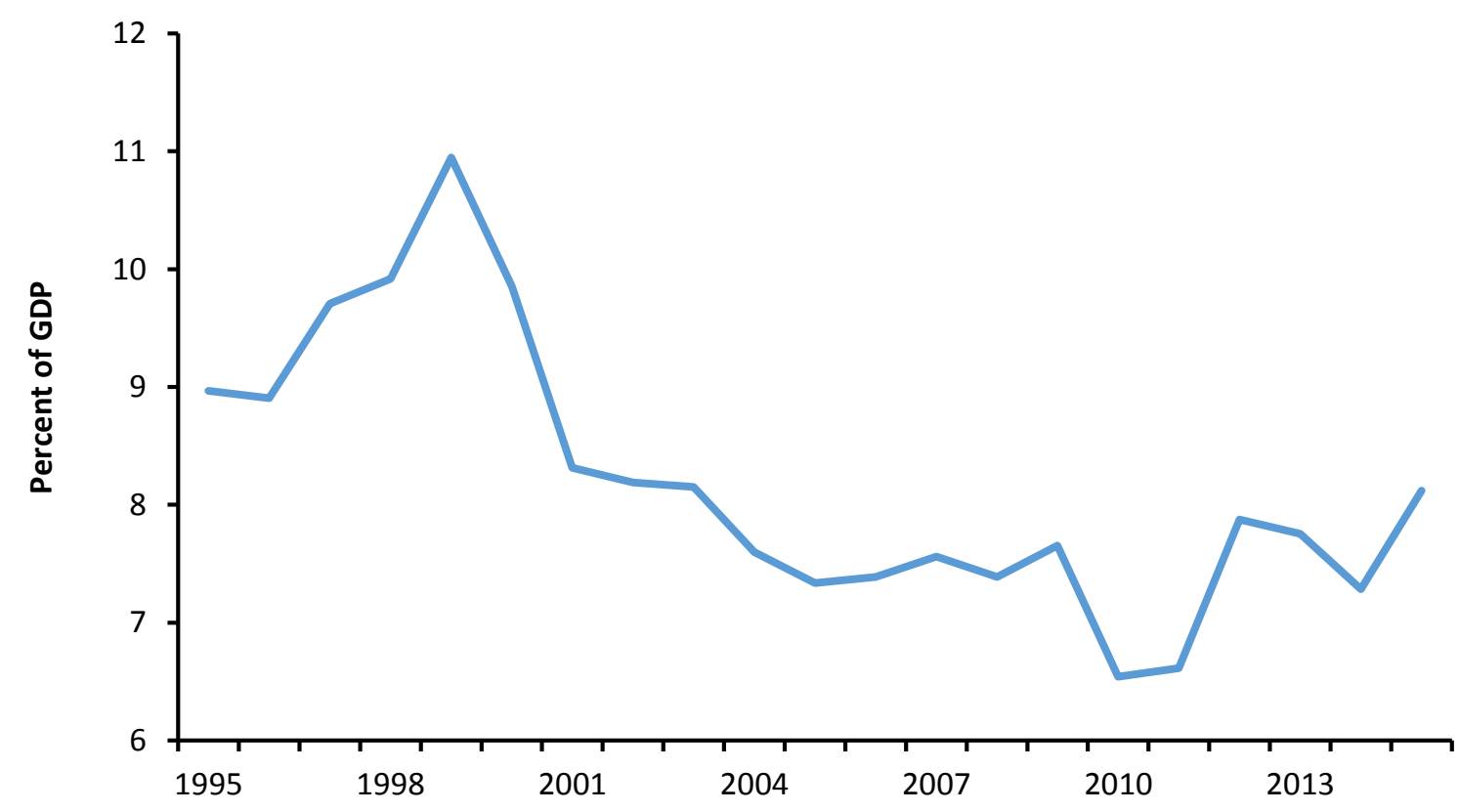

Figure 2. VAT gap due to noncompliance as percentage of GDP

Sources: Badan Pusat Statistik (Various Years); Bank Indonesia (Various Years); World Development Indicators (Various Years); World Input-Output Database (WIOD) (2013); own calculations. 
The tax reform of 2000 was deemed necessary due to the Indonesian tax authority's (Directorate General of Taxes/DGT) many deficiencies in critical aspects, which resulted in high levels of noncompliance, foregone tax revenues and increases in the cost of doing business in the country. Moreover, the poor tax administration might pose as a fundamental barrier to effective and fair taxation, as well as hinder the efforts to build wider trust between the government and its citizens (Brondolo, Silvani, Le Borgne, \& Bosch, 2008).

The next reform, which occurred in 2008/ 2009 , was initiated to extend the initial reform of 2000, with one of its goals being to improve the legal framework of tax administration. The stated purposes for the amendment of the tax laws were to provide fairer treatment, improve the delivery of service to taxpayers, improve certainty and enforcement, anticipate advances in information technology and changes in the tax regulations, improve the professionalism of the tax apparatus, enhance the tax administration's openness and increase voluntary compliance (Indonesia, 2007).

The increasing VAT gap since 2011, however, raised a question: might the reforms have failed in improving taxpayers' compliance? Although several factors, such as the institutional quality, economic growth and economic structure, matter for the levels of tax compliance in many countries (see, for example, in Agha and Haughton (1996); Christie and Holzner (2006); Sancak, Velloso, and Xing (2010)), the focus of attention in this paper is on how the implementation of tax administration reforms may affect taxpayers' compliance. This is because the most important task of any tax administration is to facilitate compliance (Bird \& Zolt, 2003), hence a viable long-term tax system depends on how effectively the tax administration carry out this task. Furthermore, as Bird (2004: 138) argued: "The problem of tax administration reform is essentially how to alter the outcomes of administrative effort by appropriate investment in developing new legal and organizational frameworks, adopting new technology (computerization), and altering the allocation of administrative resources." Hence, examining how investment in these factors has been carried out may be useful in determining the proximate causes for the suboptimal results of Indonesia's tax reforms, particularly in relation to increases in noncompliance since 2011.

Prior to the reforms, several weaknesses in the tax administration were identified in the following areas: tax collection, the tax system, legal and governance frameworks, organizational and staffing arrangements, enforcement and taxpayer service programs, and management information systems (Brondolo et al., 2008). Supported by the International Monetary Fund (IMF), reform initiatives were formulated and aimed at dealing with these factors. Hence, one of the ways to approach the question mentioned previously is by examining how these factors have been addressed.

\section{Tax collection}

As government revenue from oil and gas exploitation continues to decline, tax revenues from the non-oil and gas sectors of the economy serve as one of the key elements in the effort to sustain the government's budget. To achieve this goal, reform initiatives aimed at increasing the effectiveness of the enforcement efforts were formulated, which included identifying unregistered potential taxpayers, improving the performance of audits, improving the collection of tax arrears, as well as enforcing the filing of tax returns. It was expected that taxpayers' compliance would also increase as a response to the increased enforcement efforts of the DGT.

These initiatives produced positive results, at least until the reform of 2008/2009. The VAT gap due to noncompliance declined during the period 2000-2010. The annual average of the VAT gap in this period was 7.8 percent of GDP. It was a significant achievement compared to the gap during the previous period, 1995-1999, which reached an average of 9.7 percent of GDP. This decline in the VAT gap is consistent with increases in the tax ratio, i.e. the ratio of tax revenue to GDP. As shown in Figure 3, the tax ratio increased from 8.3 percent of GDP in 2000 to 12.8 percent of GDP in 2008. Over the longer horizon, however, these reform measures seem to produce limited results. After the reform of $2008 / 2009$, a declining trend in the tax ratio can be observed, while at around the same time there is an increasing trend in noncompliance. 


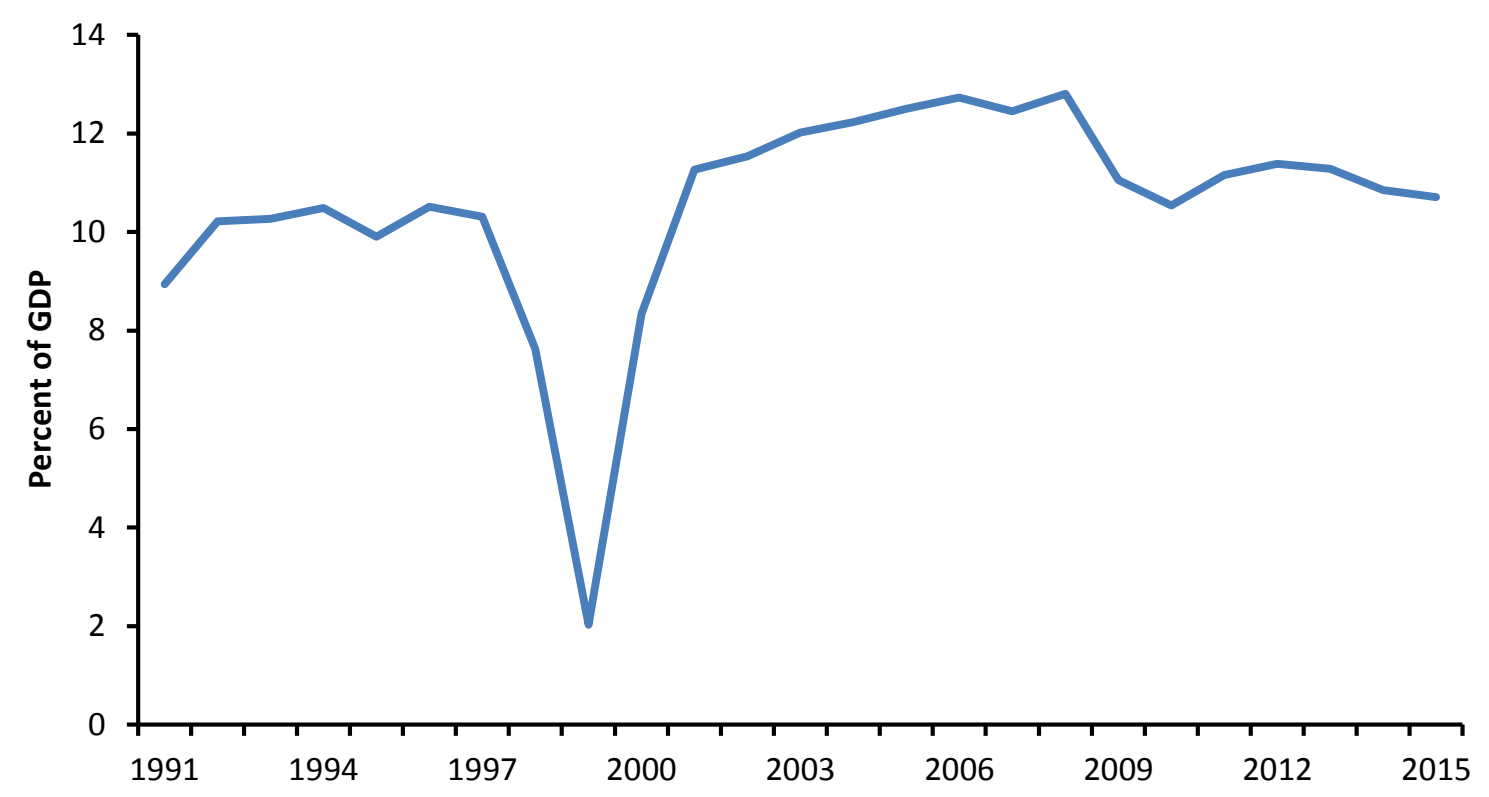

Figure 3. Tax Revenue as percentage of GDP

Sources: Badan Pusat Statistik (Various Years); Bank Indonesia (Various Years); World Development Indicators (Various Years); World Input-Output Database (WIOD) (2013); own calculations.

These adverse results might be related to the fact that some of the implementations of the reform initiatives, aimed at improving the tax revenue, were not going as expected. For example, to achieve the targeted quantity of registered taxpayers, individuals with no income, such as housewives, were given taxpayer identity numbers - often without their knowledge. This practice increases the administrative costs for the DGT and may erode the public's trust in the tax administration. Moreover, an initiative aimed at improving the quality of tax audits was hindered by the limited access to third-party data, particularly banking information. Still another example, the requirement that all VAT refund claims have to be audited makes the already limited number of auditors spend the majority of their time auditing refund claims, thus less time is dedicated to performing other audit programmes aimed at ensuring taxpayers' compliance with the tax laws.

\section{Tax system}

A complex tax system tends to make it difficult for ordinary citizens to calculate their liabilities exactly and, at some point, even to complete their tax returns. For businesses, a complex tax system could be so burdensome that it may distract them from their main objective, which is to earn profits. For many taxpayers, especially in low-middle income countries like Indonesia, hiring a tax consultant can be very expensive. Even when they can afford it, several specialist tax consultants may need to be hired for advice on complicated transactions. These compliance costs may eventually have to be borne by consumers in the form of higher prices. On the side of the tax administration, extra tax may have to be paid by taxpayers to cover any marginal costs incurred to administer the overly complex tax laws (Martin, 2005).

On the other hand, there are several benefits of simpler taxes (Gale, 2001). First, they would reduce the burden - in terms of time, money and mental anguish - to be borne by taxpayers in complying with the tax laws. Second, simpler tax incentives are more likely to be used by taxpayers and thus would be more effective in achieving their intended goals. Third, simpler taxes may increase taxpayers' compliance, as well as make enforcement easier. Fourth, in cases where the government needs to improve its 
delivery of services by raising taxes, simpler and easier to understand additional taxes might be able to generate more public support.

Nevertheless, simplifying Indonesia's tax system does not seem to be an easy task. Even after two reforms (in 2000 and 2008/2009), a survey conducted by Deloitte (2014) found that respondents considered Indonesia to be one of the top three most complex tax regimes in the Asia Pacific region - the other two countries were the Chinese mainland and India. Moreover, regarding their future expectations for Indonesia's tax regime, the respondents predicted that the country would be the third most complex in the region in 2017. The respondents also believe that in the future they may have to spend more time and resources dealing with tax issues than they currently do, due to the increasing complexity of Indonesia's tax regime. These results may indicate that the initiatives incorporated in the reforms of 2000 and 2008/2009 - particularly those addressing the issue of complexity - have yet been completely implemented.

\section{Legal and governance frameworks}

There were identified weaknesses in the legal framework of Indonesia's tax administration. On one side, the tax authority lacked many powers common to modern tax agencies, such as a strong penalty regime, access to taxpayers' records and key powers to collect tax arrears. On the other side, taxpayers lacked some basic protections, such as the easy processing of refunds, consistent tax assessments and unbiased treatment in the objection and appeal processes (Brondolo et al., 2008). Several reform initiatives were formulated to address these issues, such as increased penalties, a faster refund process for compliant taxpayers and course requirements for tax officers so that they can improve their services to taxpayers.

Until the mid-2010s, however, these weaknesses have not been fully solved. The penalty regime has not been adjusted to match inflation, thus eroding its effectiveness as a deterrence tool and the tax authority's access to banking records is still limited. Consistency in the tax regime was also problematic, as reported in the study by Deloitte (2014). The report defined consistency as "the perceived uniformity and transparency of enforcement of prevailing tax laws by the jurisdiction" (Deloitte, 2014: 11). In this aspect, the majority of respondents indicated the inconsistency of Indonesia's tax regime. According to the report, this result could be attributed to three factors: tax legislation which changes frequently; the tax authority's doctrine or publicly-available guidance, which is full of ambiguities, weaknesses and reversals; and tax disputes which take far too long to settle. An inconsistent tax authority is argued to be one that is also uncertain (Deloitte, 2014) and this condition could erode taxpayers' confidence in the tax authority.

This inconsistency may also adversely affect the performance of the DGT, because one of the factors which affects the efficiency and effectiveness of a tax administration is the stability of the tax structure over time. Frequent changes in tax legislation increase the complexity of a tax structure and could easily overload even the most sophisticated tax administration with impossible tasks (Hood, 1976). Reflecting in part the often unstable political and economic environment, there is a tendency for developing countries to alter their tax legislation frequently. Such a concern is more important when frequent changes in tax legislation have burdened the tax administration with complex tasks in an often information-poor and generally hostile environment (Bird, 2004).

Moreover, the survey by Deloitte (2014) found that arbitrary and biased tax assessments in Indonesia were still common, further eroding the taxpayers' confidence in the ability of the tax administration to resolve disputes in a fair manner. This perception of unfairness might serve as a fundamental barrier to building wider trust between the citizens and government (IMF, 2011). Further, as argued by Rothstein (2000), this lack of trust might negatively affect compliance. Rothstein (2000) maintained that when citizens do not believe that the tax authority would be honest and that the tax authority has the means to make sure that 
(almost) all the other citizens paid their taxes, then it would be unlikely that citizens would pay their fair share of taxes.

According to the slippery slope framework, one of the factors which affects compliance is the taxpayers' trust in the tax authority (Kirchler, 2007). Thus, mutual trust between the tax authority and taxpayers would lead to a synergistic tax climate where taxpayers are treated with courtesy and respect, since the tax authority trusts that taxpayers pay their taxes honestly. In return, the taxpayers would be willing to pay their fair share of taxes since they trust that the tax authority is benevolent and works beneficially for the common good (Kirchler, Hoelzl, \& Wahl, 2008). Prior research, based on national and international surveys, found that tax compliance was positively related to trust in the tax authority (Torgler, 2003; Torgler \& Schneider, 2005). Hence, it is possible that the incomplete measures for addressing weaknesses in the legal and governance frameworks may partially explain the increasing trend in noncompliance since 2011, as shown in Figure 2, through their adverse impact on taxpayers' trust.

\section{Organizational and staffing arrangements}

Prior to the reform of 2000 there were shortcomings in the DGT's organizational structure. The field offices were organized into three separate, parallel networks of units: service offices (which administered income taxes and VAT), tax audit offices and property tax offices. Each office largely operated independently of each other, hence making the accountability of results difficult to attribute to specific units. Moreover, the organizational design of the headquarters was generally not effective for managing ongoing operations and engaging in continuous reforms. The inadequate number of staff was also identified as one of the factors contributing to the DGT's poor performance in tax collection (Brondolo et al., 2008).

Due to these weaknesses, changes in the organizational design were incorporated in the reforms of 2000 and 2008/2009. The field office is now re-organized to administer all type of taxes and functions (e.g. taxpayer services, audits, arrears collection) under one roof, thus facilitating the accountability of results. Field offices are separated and based on client groups: large, medium and small taxpayers' offices. This arrangement was established to provide tighter control and specific services for the relevant groups of taxpayers. An account representative is assigned to each taxpayer, thus reducing the number of officials a taxpayer has to meet and thus minimising the chance of rent seeking behavior on the part of the tax officials.

To strengthen the capability of the headquarters in managing ongoing operations and designing reform programs, a directorate was established with the responsibility for designing reform initiatives. The Directorate of Internal Affairs was also established to manage the ethical conduct and investigate law-breaking activities by tax officials. Further, the investigation of criminal violations of tax laws is managed under a dedicated criminal investigation unit.

Nevertheless, since there are still perceived arbitrary and biased assessments by the tax authority and low confidence in its administrative procedures for resolving disputes (Deloitte, 2014), one of the most pressing issues would be to build the taxpayers' trust in the dispute administration process. In Indonesia, taxpayer's objections are administered by a unit under the DGT. The head of this unit is directly responsible to the Director General of the DGT. As such, the unit is not independent of the DGT and this organizational structure may create a conflict of interests, which might impede any fair and impartial treatment in resolving disputes.

Regarding the staffing arrangements, it is common practice that tax authorities employ a large number of staff members to administer the national tax laws. Indeed, within the next few years the DGT plans to double its staff numbers and the increasing number of taxpayer was cited as one of the factors for this expansion (Araki \& Claus, 2014). As one of the most populous countries in the world, the DGT has a relatively high ratio of labor force to tax officer, which 
stood at 3,737 persons per officer compared to the neighboring countries, such as the Philippines (3,851), Thailand (2,004) and Malaysia $(1,242)^{3}$. This ratio reflects roughly the number of registered taxpayers and potential (unregistered) taxpayers each tax officer is supposed to monitor.

Nevertheless, this ratio may not satisfactorily explain the capability - or lack of it - of the tax authorities in collecting revenue. For example, even though Thailand has a much higher ratio of labor force per tax officer than Japan $(1,172$ persons per tax officer) Thailand collected higher revenues (19.1 percent of GDP) than Japan (16.3 percent of GDP) ${ }^{4}$.

Thus, in the aspect of its staffing arrangements, it is not clear whether the number of staff employed at the DGT could explain the declining taxpayers' compliance since 2011 in Indonesia. When compliance was at its highest level in 2010, the DGT employed 32,741 staff. In 2014 the number of staff swelled to 34,510 while no improvement in compliance can be observed within this time frame (as shown in Figure 2). ${ }^{5}$ This implies that increases in the number of staff were not followed by increases in the taxpayers' compliance. ${ }^{6}$

Similarly, Bird (2004) argued that failure usually follows any tax reform strategy which requires substantial additional administrative resources - particularly staff. This is because the needed resources would not materialize fully, or in a timely fashion. Tax officers are civil servants, thus all the constraints affecting the civil services would also affect them. It is common, Bird (2004) argued, for tax authorities to experience difficulties in obtaining more staff, to have to raise wages to attract and retain staff with high qualifications, or even to acquire basic

\footnotetext{
3 Data for 2011 from Araki and Claus (2014)

4 Data for 2011 from Araki and Claus (2014)

5 Data on the number of staff members are from DGT's Annual Reports.

${ }^{6}$ One of the possible explanations might relate to how DGT manage its human resources. Nevertheless, examinations of human resources managerial aspects is beyond the scope of this study, thus further research may be needed to shed some light on this issue.
}

material needs such as computers and office space.

Recently, the international trend in addressing this problem is to set up an independent revenue authority that, to some extent, has powers to hire and pay staff, as well as access to some earmarked source of revenue (Jenkins, 1994; Manasan, 2003). Nevertheless, experience with this organizational structure in developing countries has been mixed. In some countries (e.g. Peru and Mexico), improvements seemed to have occurred, particularly in the areas of corruption eradication and the delivery of taxpayer services (Taliercio, 2000). In other instances (e.g. Peru), however, matters seemed to go well at first, following the creation of an independent revenue authority, but then they worsened rapidly; while in others (e.g. Tanzania), it seemed that there was no tangible impact which could be observed (Bird, 2004). Although beyond the scope of this paper, a tentative conclusion could be drawn: establishing an independent revenue authority may not be the panacea for poor tax administration. Countries that lack the will, strategy and resources for their efforts to reform their tax administrations are unlikely to be successful, even if they create independent revenue authorities. On the other hand, countries that have these critical ingredients probably do not need to create such an authority (Bird, 2010).

\section{Enforcement and taxpayer service programs}

The DGT's weaknesses in its audit and arrears collection functions hampered the efforts to enforce taxpayers' compliance. This lack of enforcement resulted in a narrow taxpayer base and widespread underreporting of tax liabilities. Services and assistance provided to taxpayers were severely limited, due to poor personnel management, inadequate training and the lack of a service-oriented attitude (Brondolo et al., 2008).

Hence, reform initiatives were directed towards addressing these issues. Improvements in audit programs were formulated to strengthen the capability for identifying unreported and 
underreported income and sales. Several improvements were notable. A new audit management system was installed to monitor nationwide audit processes. There were targets for the quantity and types of audit set for each auditor and field office. Further, simplified audit procedures were established for refunds claimed by compliant taxpayers with certain criteria. This way, audit resources can be focused more on auditing the less compliant.

Amid these improvements, however, the survey by Deloitte (2014) found a lack of fairness in the conduct of tax audits. The majority of respondents in the survey perceived that the Indonesian tax administration lacks respect, professionalism and proper business conduct when doing audits. This finding may imply that the reforms of 2000 and 2008/2009 have not been able to create a synergistic climate where the tax authority and taxpayer work together towards a common goal. In this climate, the tax authority holds the view that it performs a service for the community and that it is, itself, an integral part of the same community the taxpayer belongs to. Thus, transparent procedures, as well as respectful and supportive treatment of the taxpayer are the aims of the tax authority. The perception of unfairness in the conduct of tax audits, as shown in the survey by Deloitte (2014) might indicate that the reform has not yet been successful in changing the attitude of officials towards taxpayers. As the audit function holds a significant role in the selfassessment system and serves as a pillar of the tax administration (Araki \& Claus, 2014), weaknesses in this area may adversely affect the capability of the DGT to collect revenue and, more importantly, to facilitate and enforce compliance.

\section{Management information system}

After the reforms, a new information system was installed, which had the purpose of supporting the DGT's service and enforcement programmes. It was initially designed to provide a single system for monitoring taxpayers' activities and be able to reduce the need for faceto-face contact between taxpayers and tax officers, thus limiting the opportunities for rentseeking behavior by the tax officers, improving the compliance and increasing revenue.

Establishing a single management information system, however, does not seem to be an easy undertaking for the DGT. Over time, there have been expansions in the number of information systems tax officers have to use. In 2015 tax officers had to run at least six systems to control compliance and report their daily activities. Some of these systems are not able to communicate with each other, due to different programming languages. This may increase administrative complexity and the costs of monitoring taxpayer compliance.

Bird (2004: 139) argued that the ideal information system for tax administration should include, among other things, a subsystem that is able to assess the capacity of the tax base in the economy. Without it, a tax authority would not have the necessary tool to ascertain its existing and potential tax bases, as well as to formulate the appropriate policies to narrow the gap between the two. In this respect, it may be essential for Indonesia's tax authority to establish an information subsystem that can collect economic data and analyze them, in order to have better information on, for example, the revenue consequences of tax reform proposals, the impact of proposed tax changes on income distribution and equity, as well as a better ability to estimate future tax revenues. All of this would lead to a tax system which is better designed and administered (Bird \& Zolt, 2008).

\section{CONCLUDING REMARKS}

This paper has reviewed Indonesian tax reforms post-Asian financial crisis, with emphasis given to reviewing the reform efforts aimed at improving the capacity of the tax administration. Although the institutional environment in which a tax system operates may affect the taxpayers' compliance behavior, how taxes are administered may also hold an important role in altering this behavior - either in a positive or negative direction.

Closer examination suggests that the taxpayers' compliance will improve when the 
majority of the tax reform initiatives are properly implemented. On the contrary, compliance would deteriorate if the reform process suffered from decelerations, setbacks and reversals. Such incomplete reform might erode the taxpayers' trust in the tax authority in particular, and the government in general (Alm, Martinez-Vazquez, \& Torgler, 2010; Bird, Martinez-Vazquez, \& Torgler, 2008). If this condition emerges, the scope to raise extra government revenues would be limited. This would be a source of great concern when there are budgetary pressures due to the rising demand for public expenditure.

Tax reform is a continuous process. Improved compliance with the tax laws does not come by itself. It has to be created, cultivated, monitored and enforced at all times (Bird, 2004). In this regard, there are several approaches which could be considered in an effort to improve compliance. First, looking back at the reform initiatives contained in the reforms of 2000 and 2008/2009 might be advantageous. Identifying which initiatives have been implemented successfully and which have not, or even those not yet carried out, might be a good start in the effort to halt the deterioration in compliance and reverse its trend.

Second, getting advice and technical assistance from international agencies might be helpful. Sustaining tax reforms over time requires that a country's tax authority holds the ownership of the reform process. Nevertheless, international agencies could provide valuable advice and expertise in the design and implementation of reform programmes. Improved compliance in 2000-2010 happened when the tax reforms were under the guidance of international agencies, while deteriorations in compliance since 2011 took place at the same time as the advisory role of these agencies was reduced.

Third, the tax gap may need to be estimated and monitored systematically and continuously. These tax gap estimates could provide a broad view of citizens' compliance with the tax laws. If it is done on a systematic and continuous basis, the tax authority would be able to assess taxpayers' compliance behavior over time, analyze its proximate causes and formulate appropriate policies in a timely manner.

\section{REFERENCES}

Agha, A., \& Haughton, J. (1996). Designing VAT systems: Some efficiency considerations. The Review of Economics and Statistics, 303-308.

Alm, J., Martinez-Vazquez, J., \& Torgler, B. (2010). Developing alternative frameworks for explaining tax compliance: Routledge.

Araki, S., \& Claus, I. (2014). A Comparative Analysis on Tax Administration in Asia and the Pacific: Asian Development Bank.

Badan Pusat Statistik. (Various Years). Statistik Indonesia. Jakarta: Badan Pusat Statistik.

Bank Indonesia. (Various Years). Indonesian Financial Statistics. Retrieved from: http://www.bi.go.id/en/statistik/seki/terkini/ keuangan-pemerintah/Contents/Default.aspx

Barbone, L., Belkindas, M., Bettendorf, L., Bird, R. M., Bonch-Osmolovskiy, M., \& Smart, M. (2013). Study to quantify and analyse the VAT Gap in the EU-27 Member States. CASE Network Reports(116).

Berhan, B. A., \& Jenkins, G. P. (2005). The high costs of controlling GST and VAT evasion. Canadian Tax Journal, 53(3), 720.

Bird, R. M. (2004). Administrative dimensions of tax reform. Asia-Pacific Tax Bulletin, 10(3), 134-150.

Bird, R. M. (2010). Smart Tax Administration. World Bank-Economic Premise(36), 1-5.

Bird, R. M., Martinez-Vazquez, J., \& Torgler, B. (2008). Tax effort in developing countries and high income countries: The impact of corruption, voice and accountability. Economic Analysis and Policy, 38(1), 5571.

Bird, R. M., \& Zolt, E. M. (2003). Introduction to tax policy design and development. Prepared for a course on "Practical Issues of Tax Policy in Developing Countries," World Bank, (28).

Bird, R. M., \& Zolt, E. M. (2008). Technology and taxation in developing countries: from hand to mouse. National Tax Journal, 791821.

Brondolo, J., Silvani, C., Le Borgne, E., \& Bosch, F. (2008). Tax administration reform 
and fiscal adjustment: the case of Indonesia (2001-07). IMF Working Papers, 1-70.

Casanegra de Jantscher, M. (1990). Administering the VAT. In M. Gillis, C. S. Shoup \& G. P. Sicat (Eds.), Value-Added Taxation in Developing Countries. Washington: World Bank.

Christie, E., \& Holzner, M. (2006). What explains tax evasion? An empirical assessment based on European data: The Vienna Institute for International Economic Studies, wiiw.

De Paula, A., \& Scheinkman, J. A. (2010). Value-added taxes, chain effects, and informalit. American Economic Journal: Macroeconomics, 2(4), 195-221.

Deloitte. (2014). Risk, uncertainty and opportunity in a changing tax landscape: Deloitte Touche Tohmatsu Ltd.

Ebrill, L., Keen, M., Bodin, J.-P., \& Summers, V. (2001). The Modern VAT. Washington, D.C.: International Monetary Fund.

Eichhorn, C. (2004). Tax Evasion and Economic Growth-A Neutrality Result. Unpublished Working Paper. University of Munich.

Freire-Serén, M. J., \& i Martí, J. P. (2013). Tax avoidance, human capital accumulation and economic growth. Economic modelling, 30, 22-29.

Gale, W. G. (2001). Tax simplification: issues and options. Tax Notes, 92(11), 1463-1483.

Gillis, M. (1989). Comprehensive Tax Reform: The Indonesian Experience, 1981-1988. In M. Gillis (Ed.), Tax reform in developing countries. Durham, USA: Duke University Press.

Hood, C. (1976). The limits of administration: London; Toronto: Wiley.

Hutton, E., Thackray, M., \& Wingender, P. (2014). Uganda: Revenue Administration Gap Analysis Program - The Value-Added Tax Gap: International Monetary Fund Fiscal Affairs Department.

Ikhsan, M., Trialdi, L., \& Syahrial, S. (2005). Indonesia's new tax reform: Potential and direction. Journal of Asian Economics, 16(6), 1029-1046.

IMF. (2011). Revenue Mobilization in Developing Countries: IMF.
Undang-Undang Nomor 28/2007, Government of the Republic of Indonesia (2007).

Jenkins, G. (1994). Modernization of tax administrations: revenue boards and privatization as instruments for change: JDI Executive Programs.

Keen, M., \& Smith, S. (2006). VAT fraud and evasion: What do we know and what can be done? National Tax Journal, 861-887.

Kirchler, E. (2007). The economic psychology of tax behaviour: Cambridge University Press.

Kirchler, E., Hoelzl, E., \& Wahl, I. (2008). Enforced versus voluntary tax compliance: The "slippery slope" framework. Journal of Economic Psychology, 29(2), 210-225.

Kopczuk, W., \& Slemrod, J. (2006). Putting firms into optimal tax theory. The American Economic Review, 96(2), 130-134.

Le, T. M. (2003). Value-added Taxation: Mechanism, Design, and Policy Issues. course on Practical Issues of Tax Policy in Developing Countries, April.

Manasan, R. G. (2003). Tax Administration Reform: Semi-Autonomous Revenue Authority, Anyone? Philippine Journal of Development, 30(2), 173.

Martin, D. (2005). Tax simplification: how, and why, it must be done. Surrey: Centre for Policy Studies.

Moore, M. (2013). Obstacles to increasing tax revenues in low income countries. International Centre for Tax and Development Working Paper, 15.

Pomeranz, D. (2015). No taxation without information: Deterrence and selfenforcement in the value added tax. The American Economic Review, 105(8), 25392569.

Reckon, L. (2009). Study to quantify and analyse the VAT gap in the EU-25 member states. Report for DG Taxation and Customs Union, September.

Rothstein, B. (2000). Trust, social dilemmas and collective memories. Journal of Theoretical Politics, 12(4), 477-501.

Sancak, C., Velloso, R., \& Xing, J. (2010). Tax revenue response to the business cycle. IMF Working Papers, 1-21. 
Smith, S., \& Keen, M. (2007). VAT Fraud and Evasion: What do we know, and What Can be Done? IMF Working Papers, 1-33.

Taliercio, R. (2000). Evaluating reform through survey data: the impact of revenue authorities on corporate taxpayer assessments of administrative competence, efficiency and fairness. (Master's Thesis), Harvard University, Massachusetts, USA.

Torgler, B. (2003). Tax morale, rule-governed behaviour and trust. Constitutional Political Economy, 14(2), 119-140.

Torgler, B., \& Schneider, F. (2005). Attitudes towards paying taxes in Austria: An empirical analysis. Empirica, 32(2), 231250.

Utami, S. S. (2016). Hanya 900.000 Wajib Pajak Pribadi yang Bayar Pajak [Only 900.000 individual taxpayers pay taxes]. Retrieved from http://ekonomi.metrotvnews.com/makro/8K yOe8rb-hanya-900-000-wajib-pajakpribadi-yang-bayar-pajak

World Development Indicators. (Various Years). World Development Indicators. Retrieved from: http://data.worldbank.org/indicator/

World Economic Outlook. (2016). World Economic Outlook Database. Retrieved from:

http://www.imf.org/external/pubs/ft/weo/20 16/01/weodata/index.aspx

World Input-Output Database (WIOD). (2013). World Input-Output Database. Retrieved 1 July 2016 http://www.wiod.org/new_site/ database/niots.htm 
Appendix A

VAT Theoretical Liability (VTL), 1995-2015 (million US\$)

\begin{tabular}{|c|c|c|c|}
\hline Year & $\begin{array}{c}\text { VTL from } \\
\text { Household } \\
\text { Consumption }\end{array}$ & $\begin{array}{c}\text { VTL from } \\
\text { Government \& } \\
\text { NPISH } \\
\text { Consumption }\end{array}$ & $\begin{array}{c}\text { VTL from } \\
\text { Intermediate } \\
\text { Consumption by } \\
\text { Industries }\end{array}$ \\
\hline 1995 & 16,111 & 1,881 & 7,539 \\
\hline 1996 & 18,558 & 2,066 & 8,924 \\
\hline 1997 & 18,198 & 1,852 & 9,346 \\
\hline 1998 & 7,876 & 608 & 3,874 \\
\hline 1999 & 12,467 & 1,023 & 6,048 \\
\hline 2000 & 12,362 & 1,211 & 6,429 \\
\hline 2001 & 11,873 & 1,271 & 5,635 \\
\hline 2002 & 14,896 & 1,614 & 6,796 \\
\hline 2003 & 17,751 & 2,139 & 8,092 \\
\hline 2004 & 18,489 & 2,328 & 8,395 \\
\hline 2005 & 19,880 & 2,531 & 9,135 \\
\hline 2006 & 25,637 & 3,564 & 12,235 \\
\hline 2007 & 30,842 & 4,092 & 14,382 \\
\hline 2008 & 35,764 & 4,992 & 17,095 \\
\hline 2009 & 36,519 & 5,981 & 18,347 \\
\hline 2010 & 46,688 & 7,479 & 24,146 \\
\hline 2011 & 54,432 & 8,991 & 29,671 \\
\hline 2012 & 68,326 & 8,173 & 31,794 \\
\hline 2013 & 67,775 & 8,107 & 31,613 \\
\hline 2014 & 66,142 & 7,912 & 30,879 \\
\hline 2015 & 64,121 & 7,670 & 29,787 \\
\hline
\end{tabular}

Sources: Badan Pusat Statistik (Various Years); Bank Indonesia (Various Years); World Development Indicators (Various Years); World Input-Output Database (WIOD) (2013); own calculations. 


\section{Appendix B}

VAT Gap, 1995-2015

\begin{tabular}{cccccc}
\hline Year & $\begin{array}{c}\text { VAT Total } \\
\text { Theoretical } \\
\text { Liability } \\
\text { (Million US } \$ \text { ) }\end{array}$ & $\begin{array}{c}\text { Actual VAT } \\
\text { Collection } \\
\text { (Million US } \$ \text { ) }\end{array}$ & $\begin{array}{c}\text { VAT Gap } \\
\text { (Million US } \$ \text { ) }\end{array}$ & $\begin{array}{c}\text { GDP } \\
\text { (Million US } \$ \text { ) }\end{array}$ & $\begin{array}{c}\text { VAT Gap as } \\
\text { Percentage of } \\
\text { GDP }(\%)\end{array}$ \\
\hline 1995 & 25,531 & 7,407 & 18,124 & 202,132 & 8.97 \\
1996 & 29,549 & 9,302 & 20,247 & 227,370 & 8.90 \\
1997 & 29,396 & 8,456 & 20,940 & 215,749 & 9.71 \\
1998 & 12,358 & 2,890 & 9,468 & 95,445 & 9.92 \\
1999 & 19,538 & 4,213 & 15,325 & 140,001 & 10.95 \\
2000 & 20,002 & 3,743 & 16,259 & 165,021 & 9.85 \\
2001 & 18,779 & 5,442 & 13,337 & 160,447 & 8.31 \\
2002 & 23,306 & 7,282 & 16,024 & 195,661 & 8.19 \\
2003 & 27,982 & 8,845 & 19,137 & 234,772 & 8.15 \\
2004 & 29,212 & 9,700 & 19,512 & 256,837 & 7.60 \\
2005 & 31,546 & 10,579 & 20,967 & 285,869 & 7.33 \\
2006 & 41,436 & 14,507 & 26,929 & 364,571 & 7.39 \\
2007 & 49,316 & 16,635 & 32,681 & 432,217 & 7.56 \\
2008 & 57,851 & 20,153 & 37,698 & 510,229 & 7.39 \\
2009 & 60,848 & 19,546 & 41,302 & 539,580 & 7.65 \\
2010 & 78,313 & 28,927 & 49,386 & 755,094 & 6.54 \\
2011 & 93,094 & 34,028 & 59,066 & 892,969 & 6.61 \\
2012 & 108,293 & 35,964 & 72,328 & 917,870 & 7.88 \\
2013 & 107,496 & 36,775 & 70,721 & 912,524 & 7.75 \\
2014 & 104,933 & 40,082 & 64,851 & 890,815 & 7.28 \\
2015 & 101,579 & 31,645 & 69,934 & 861,256 & 8.12 \\
\hline
\end{tabular}

Sources: Badan Pusat Statistik (Various Years); Bank Indonesia (Various Years); World Development Indicators (Various Years); World Input-Output Database (WIOD) (2013); own calculations.

Notice: The Journal of Indonesian Economy and Business and its Board of Editors are not responsible for any errors or flaws found in this article. The authors take full responsibility for their work. 